ISSN: 2362-1303 (Paper) | eISSN: 2362-1311(Online)

JOURNAL OF ADVANCED ACADEMIC RESEARCH (JAAR)

July 2016

\title{
Spatial Analysis of Cob-Douglas Production Function in Agriculture Sector of Nepal: An Empirical Analysis
}

\author{
Thakur Prasad Sharma Wagle
}

PhD Scholar, Mewar University, Chittorgarh, Rajasthan, India

Associate Professor, Institute of Science \& Technology, TU

\begin{abstract}
This paper examines use of the Cob-Douglas production function on the agricultural production in various space and dimensions. The objective of this study is to investigate the logical relationship between production and expenditure as well as labour. This research is to develop aunorthodox model for production function in Nepal. Analysis of the basic model used for estimation, estimates of elasticity of substitution equation on National agricultural panel data from economic survey (1983/84 - 2013/14) in averages. The empirical regression reveals that, sum of the regression coefficients is less than unity i.e., 0.976.So, system is less efficient or 'diminishing return to scale. In fact, for every 100 percent of inputs increases (agriculture expenditure and labour) we can expect only 97.60 percent of output (GDP contribution from agriculture). This is a less efficient trend of the agriculture production in developing country like Nepal. It is clear to see that the Checking results consistency with theory and Robustness of the conclusion.
\end{abstract}

KEYWORDS: Consistency, Diminishing, Elasticity, Production Function, Robustness, Spatial, Unorthodox

\section{INTRODUCTION}

Agriculture is the main source of food, income, and employment for the majority of the Nepalese peoples. The economy is dominated by agriculture, where agriculture has been the highest priority because economic growth was dependent on both increasing the productivity of existing crops and diversifying the agricultural base for use as industrial inputs. Agriculture in Nepal is always risky and therefore if you try to change something it becomes more risky. Nepal is an agricultural country; about 83 percent of the people's occupation is agriculture (census of agriculture 2011/12).

In Nepal, Agriculture sector has been playing a vital role in the Nepalese economy. The sector's role has been important mainly due to its significant contribution to avail employment 0pportunities to the entire rural farmer communities and food security to the nation at large. In the context of open international market, it has become an utmost necessity to make this sector efficient to benefit from comparative advantage and competition through commercialization and diversification, based on available means and resources; Agriculture sector has been receiving top priority since the Fifth Five-Year plan. Special emphasis is given to the formulation of time-conductive agricultural policies, effective implementation and their monitoring and evaluation aspects for the development of this sector. The entire programs of agriculture developments are directed towards 
ISSN: 2362-1303 (Paper) | eISSN: 2362-1311(Online)

bringing positive changes in the lifestyles of majority of agricultural communities by enhancing overall agricultural production and productivity

Contribution of agriculture sector to the Nepalese economy has been noteworthy. The agriculture sector occupies almost one third of Gross Domestic Product (GDP) with about two third of country's population are dependent in this sector. Contribution of this sector to GDP was 33.87 percent in fiscal year 2012/13, which is expected to remain at 33.10 percent in fiscal year 2013/14. In fiscal year 2070/71, the annual growth rate of agriculture sector is expected to be 4.72 percent at constant prices of 2000/01(Economic Survey 2013/14). The time series data are non-stationary; if its characteristics i.e. mean variance and covariance are time variant that is they do change over time.

The production function named after two economists C.W. Cobb and P.H. Douglas is known as C-D production function. This production is widely used in economic analysis. A production function in which two inputs $\mathrm{K}$ and $\mathrm{L}$ are expressed in multiplicative form is known as C-D production function. It can be expressed as

$$
\mathrm{Q}=\mathrm{AK}^{\alpha} \mathrm{L}^{\beta}
$$

Where $A>0:$ Technical / efficiency parameter

$$
\alpha, \beta>0 \text { : Share of capital and labour/Substitution parameter }
$$

Homogeneity

$$
\begin{aligned}
& \text { Multiplying } \mathrm{k} \text { and } \mathrm{L} \text { by } \lambda \text { times } \\
& \begin{array}{l}
\mathrm{Q}=\mathrm{AK}^{\alpha} \mathrm{L}^{\beta} \\
=\mathrm{A}(\lambda \mathrm{k})^{\alpha}(\lambda \mathrm{L})^{\beta}
\end{array} \\
& =\lambda^{\alpha+\beta} . \mathrm{Q}
\end{aligned}
$$

Thus C-D.production function is homogeneous of degree $(\alpha+\beta)$. If $\alpha+\beta>1$ is increasing returns to scale (IRS). If $\alpha+\beta<1$ is decreasing returns to scale (DRS). If $(\alpha+\beta)=1$ is constant returns to scale (CRS) (Gujarati 2013).

$\mathrm{C}-\mathrm{D}$ production function is linear homogeneous

When,

$$
\text { or, } \beta=1-\alpha
$$

$$
(\alpha+\beta)=1
$$

Thus the linear homogeneous $\mathrm{C}-\mathrm{D}$ production function is

$$
\mathrm{Q}=\mathrm{AK} \mathrm{K}^{\alpha} \mathrm{L}^{1-\alpha}
$$

\section{Objectives of the Research}

The general objective of this research is to develop a Cobb-Douglas production model so that existing methods of time series modeling and forecasting can be improved. The study also aims to provide an estimate of future values of the series based on previously observed values. Such an estimate may be obtained from a mathematical model which generates the time series. If there are known underlying deterministic equations they can be solved to predict future observations based on knowledge of initial conditions. An approach for combining different model has been proposed to capture both linear and non-linear pattern in the data, then validate the approach by evaluating the performance with single models, in particular to provide the relevant econometric models for the development of agriculture 
ISSN: 2362-1303 (Paper) | eISSN: 2362-1311(Online)

JOURNAL OF ADVANCED ACADEMIC RESEARCH (JAAR)

July 2016

crops to planners, policy makers and researchers. However, the specific objectives of the research are followings.

(a) To develop Cobb-Douglas production function/model with real data sets in agriculture of Nepal and then to establish logical relationship between productions function (output) and inputs of expenditure and labour.

(b) To increase agriculture production by pursuing adaptive agricultural research and development.

The concept of model combination has arisen in forecasting practice since no single model is able to capture the patterns in the data in all circumstances.

\section{Previous Empirical studies}

There are a few researches in this area in Nepalese contest. More appropriate and relevant literatures are included in here. Thapa (2012) evaluated the empirical issues pertaining to technology adoption decisions agriculture commodities, price changing rapidly (volatility) and the effects of remittances recipient households, combined with the motivation of migration decisions in Nepal under the theories of incomplete and imperfect markets. This work applies a number of econometric models to test a number of the hypothesis using both panel and cross-section data from the Nepal living standard surveys and time series data for commodity prices and farm yields. The findings show that as geographical heterogeneity seems to be major constraint for market integration, well-functioning factor markets and well-developed infrastructure emerge as the precondition for agricultural-led growth in Nepal. Moreover, the study also shows that rural people with large family size and higher per capita income without remittances have higher probability to go migrate. Evidence further shows that remittance decrease work hours in a number of sectors, but increase work hours of hired labour in remittance receiving households. Remittance income seems to be a substitute of non-labour income for remittance-receiving households.

Gujarati, Damodar (2011) had published the most popular research book entitled "Ecoometrics by example". He had examined various regression models; the relevant and appropriate production model in agriculture sector is the cobb-Douglas production function. It is frequently used in empirical analysis. It satisfied the log-linear or double log or constant elasticity models, where the regress and (output) as well as the regressors (inputs) are all in logarithmic form. We consider the celebrated cobb-douglas(CD) production function, which may be expressed as:

$\mathrm{Q}_{\mathrm{i}}=\mathrm{B}_{1} \mathrm{~L}_{\mathrm{i}}{ }_{2} \mathrm{~K}_{\mathrm{i}}{ }^{\mathrm{B}}{ }_{3} \mathrm{e}_{\mathrm{i}}^{\mathrm{u}_{\mathrm{i}}}$

Where $\mathrm{Q}=$ output, $\mathrm{L}=$ labor input, $\mathrm{K}=$ capital, $\mathrm{B}_{1}=$ constant and $\mathrm{u}_{\mathrm{i}}=$ error terms, further $\mathrm{B}_{2}$ and $\mathrm{B}_{3}$ are partial slope coefficients or elasticities

Thapa, Sridhar (2007) had written a research article entitled "The relationship between farm size and productivity" empirical evidence from the Nepalese mid hills published by (Nepoli, 13-14 sept, Italy).This paper examines the farm size and productivity relationship using data from Nepalese mid hills. The household data used has been drawn from a survey conducted by the author and financed by the Norwegian university of life science. The 
ISSN: 2362-1303 (Paper) | eISSN: 2362-1311(Online)

analysis uses models both allowing for and not allowing for village dummies (as cluster controls) the ratio of irrigated land (as proxy for land quality) and other socio-economic variables such as households, belonging to caste groups and family size (as proxy for access to resources). The result supported the almost 'stylized fact' of inverse relationship (IR) between farm size and output per hectare. Total cash input use and labour hours per hectare were found to be higher as small farms. The findings of regression equation allowing for village dummies and other socio-economic variables do not support the explanation that the IR between farm size productivity is due to variation in regions as well as access to resources. Nevertheless, family size and caste dummies show some effects on farm value added. The paper further investigates returns to scale in Nepalese agriculture, applying the Cobb-Douglas (CD) production function. The result shows constant returns to scale. Labor input seems more influential in farm production, followed by manure, in the sample farms, the overall results shows that the IR between farm size and output per hectare is perhaps due to the results more of other inputs used by small farms rather than diseconomies of scale.

Dilly (2004, Aryal) had examined about ARMIA model entitled "study on hybrid BoxJenkings ARIMA and neutral networks model for time series forecasting and decision making". He reported that time series foresting is important to a wide range of disciplines both the physical and social sciences for proactive policy decisions. The accuracy of time series foresting is fundamental to many decision processes. Therefore, the research for improving the effectiveness of forecasting models has become more interesting to the scholars. This thesis describe the work undertaken to investigate and develop methodologies for time series prediction of complex real world time series using principles from the hybridization that combine the linear and non-linear models together. In this work, various available techniques that had been used to solve other problems are brought together. Modified and adapted and combined with the new ideas to from a time series prediction hybrid methodology that extract both linear and non-linear pattern present in the data.

Zhengfei Guan (2005) mentioned in applied research thesis entitled "Econometric analysis of agriculture production." It is mention below.

Evidence in the literature suggests that dual approach of production analysis, albeit elegant in concept, is either incorrect or inefficient in practice, calling for reviving of the primal. However, the generic production models of the primal approach do not respect agronomic reality and lack a solid theoretical foundation.

This research acknowledges the relevance of agronomic knowledge in economic analysis of production, recognizing distinct functionalities of inputs. The research proposes a dichotomy provides a new paradigm for imperial production analysis.

Economic Survey (2013/14) revealed that production of the agriculture sector is estimated to grow by 4.7 percent in fiscal year 2013/14. Such growth rate was just 1.1 percent last year. The non-agriculture sector is estimated to grow by 5.3 percent in current fiscal year, while this sector had grown by 4.6 percent last year. Among the non-agriculture sector, 
ISSN: 2362-1303 (Paper) | eISSN: 2362-1311(Online)

growth rates of industry and services sector are estimated to remain at 2.7 percent and 6.1 percent respectively in current fiscal year while these figures were 2.5 percent and 5.2 percent respectively in the previous fiscal year. Growth rates of Electricity, gas and water, construction wholesale and retail trades, hotel and restaurant, fiscal intermediation, real estate, education sectors under the non-agriculture sector have increased as compared to the previous year.

Satyal, V.R. (2011) argued in Economic Journal of Development of issues vol.11 pp 1-18, the concluded that Despite decade long investment and planning in Agriculture it is declining in terms of production and engaged labour force. If such structural shift were natural it would be satisfactory. However, in absence of sustainable development in other sector like service or industry, such shift could be very dangerous for the country whose primitive knowledge, life style, culture, religion are based on agriculture. This paper attempts to show the current disappointment in agriculture and analyses some causes for the decline with few recommendations for improvement.

Wagle, T.P (2014) has written in research publication "Journal of Development Review" on the research topic Agriculture Production in Nepal: A Theoretical and an Empirical Analysis. Researcher identified that In Nepal, 83 percent of population works in the agriculture sector, whereas average growth rate in agriculture sector at 2069/070 is 3.6, and economic growth rate 4.0 in averages. The study investigated the relationships between the agriculture production and economic growth of Nepal using secondary data. The time period selected is from (1998/99 to 2007/08), the ministry of agriculture. Regression model is used to assess the degree of relationships among variables concerned which show significant relationship between agriculture production and economic growth of Nepal.

The above result shows that the $R^{2}$ is 0.98 , which shows that the model explains about 98 percent of the variation in agriculture production on the basis of area and other constants. It is found that the parameter estimates is positively signed and the $t$ - statistic for area and various horticultures are statistically significant at 5 percent level. It indicates that agriculture production has significant impact on Nepal's economic growth. So it creates paradigm shift from orthodox way of analysis of data to innovative way of interpretation. The common goal is to guide both agriculture development and antipoverty creation in policy-making level, so that those common objectives can be realized for the benefit of poor consumers and poor farmers.

\section{METHOD}

The quantitative research is based on inferential statistics, for testing objective theories by examining the relationship among variables with structural bases, and testing Cob-Douglas production function by using deductive methods. In production function we establish the cause and effect relationship between food and agriculture production on labour and capital. The study is mainly based on secondary data have been collected from the various issues of agriculture survey published by central bureau of statistics. As the study is based on time series data from Economic Survey Fiscal Year (2013/14) in a macro-economic level. 
ISSN: 2362-1303 (Paper) | eISSN: 2362-1311(Online)

To spatial analyze, the data SPSS Vs 20 is used for Cob-Douglas production function. The target variable food and agriculture production is put in the dependent variable and labour and capital are in the independent variables with constant prices then to check in estimates and in model fit. The output window of SPSS pups up with several output sections, the output in annex -02 serve our purpose for this study.

\section{Model specification}

Model specification is a mathematical expression showing the inter-relationship between the economic relationship existing between economic variables(dependent and independent). The model is a three -variable model and stated covers the gross domestic product (GDP) at constant prices as the dependent variable to capture economic growth while agricultural sector output and labour, expenditure have the independent variables to capture government expenditure on agriculture in Nepal.

Given the foregoing discussion, the following model is specified in order to determine the impact of agriculture production on economic growth in Nepal.

The production function named after two economists C.W. Cobb and P.H. Douglas is known as C-D production function. This production is widely used in economic analysis. A production function in which two inputs $\mathrm{K}$ and $\mathrm{L}$ are expressed in multiplicative form is known as C-D production function. In functional form, the Cob-Douglas production function is;

$\mathrm{Q}=\mathrm{AK} \mathrm{K}^{\alpha} \mathrm{L}^{\beta}$

Where $\mathrm{A}>0$ : Technical / efficiency parameter

$\alpha, \beta>0$ : Share of capital and labour / Substitution parameter

Homogeneity

Multiplying $\mathrm{k}$ and $\mathrm{L}$ by $\lambda$ times

$$
\begin{aligned}
\mathrm{Q}=\mathrm{AK}^{\alpha} \mathrm{L}^{\beta} & (\therefore \alpha+\beta)=1, \beta=1-\alpha) \\
& =\mathrm{A}(\lambda \mathrm{k})^{\alpha}(\lambda \mathrm{L})^{\beta} \\
& =\mathrm{A} \lambda^{\alpha+\beta} \cdot \mathrm{Q}
\end{aligned}
$$

Thus C.D. production function is homogeneous of degree $(\alpha+\beta)$. If $\alpha+\beta>1$ increasing returns to scale (IRS) If If $\alpha+\beta<1$ decreasing returns to scale (DRS) If $(\alpha+\beta)=1$ constant returns to scale. (CRS)

$\mathrm{CD}$ production function is linear homogeneous

When,

$$
\text { Or, } \beta=1-\alpha
$$

$$
(\alpha+\beta)=1
$$

Thus the linear homogeneous $\mathrm{C}-\mathrm{D}$ production function is $\mathrm{Q}=\mathrm{AK}^{\alpha} \mathrm{L}^{1-\alpha}$

(1) $\alpha$ and 1- $\alpha$ represent the share of corresponding input when paid by its MP.

$$
\begin{aligned}
& \mathrm{M} P_{k}=\frac{K_{\partial K}^{\partial Q}}{Q}=\frac{K \partial\left(A K^{\alpha} L^{1-\alpha}\right) / \partial K}{A K^{\alpha} L^{1-\alpha}}=\frac{\alpha K^{\alpha}}{k^{\alpha}}=\alpha \\
& \mathrm{MP}_{2}=\frac{L_{\partial L}^{\partial Q}}{Q}=\frac{L \cdot \partial\left(A K^{\alpha} L^{1-\alpha}\right) / \partial L}{A K^{\alpha} L^{1-\alpha}}=\frac{L \cdot A K^{\alpha}(1-\alpha) L^{-\alpha}}{A K^{\alpha} L^{1-\alpha}}=\frac{L^{1-\alpha} \cdot A K^{\alpha}(1-\alpha)}{A K^{\alpha} L^{1-\alpha}}
\end{aligned}
$$


ISSN: 2362-1303 (Paper) | eISSN: 2362-1311(Online)

$(2)=(1-\alpha)$ or, $\beta$ where $\alpha$ and (1- $\alpha)$ represent partial elasticity of output.

$$
e_{k}=\frac{\frac{\partial Q}{Q}}{\frac{\partial K}{K}}=\frac{\partial Q}{\partial K} \cdot \frac{K}{Q}=\frac{\partial A K^{\alpha} L^{\beta}}{\partial K} \cdot \frac{K}{K^{\alpha} L^{\beta}}=A \alpha K^{\alpha-1} L^{\beta} \cdot \frac{K}{A K^{\alpha} L^{\beta}}=\frac{\alpha K^{\alpha}}{K^{\alpha}}=\alpha
$$

Similarly elasticity of labour $\left(\mathrm{e}_{1}\right)$

$e_{1}=\frac{\frac{\partial Q}{Q}}{\frac{\partial L}{L}}=\frac{\partial Q}{\partial L} \cdot \frac{L}{Q}=\frac{\partial A K^{\alpha} L^{\beta}}{\partial L} \cdot \frac{L}{A K^{\alpha} L^{\beta}}=A K^{\alpha} \beta L^{\beta-1} \cdot \frac{L}{A K^{\alpha} L^{\beta}}=\frac{\beta \cdot L^{\beta}}{L^{\beta}}=\beta$

Conclusion: This implies that relative shares of two parameters remain on certain proportion.

\section{A Priori Expectations or $\mathrm{H}_{1}$ testing:}

$$
\mathrm{LnQ}=\mathrm{B}_{0}+\mathrm{B}_{1} \ln \mathrm{k}+\mathrm{B}_{2} \ln \mathrm{L}+\mathrm{u}_{\mathrm{i}}
$$

Research Hypothesis:

For studying the superiority of comprehensive productivity to net labour as well as expenditure for better outputs of production of agriculture, so we test the following hypothesis.

Null Hypothesis $\mathrm{H}_{\mathrm{O}}$

There is no relationship between the value of agriculture production per acre and the labour as well as expenditure.

Alternative Hypothesis $\mathrm{H}_{1}$

There is statistically significant between the value of agriculture production per acre and the labour as well as expenditure.

Where $\mathrm{B}_{0}, \mathrm{~B}_{1}, \mathrm{~B}_{2}>0$

The a priori expectations of this model are based on the knowledge of the world economic theory. This implies that agriculture production on expenditure of government have a positive sign and thus denoting a positive relationship with GDP ( economic growth ) which is expected to exist.

It is also expected that the coefficient of total government expenditure should be positive. Thus the following is the a priori expectation of the model is :

$$
\mathrm{B}_{0}>0, \mathrm{~B}_{1}>0, \mathrm{~B}_{2}>0, \mathrm{u}_{\mathrm{i}}=0
$$

$\mathrm{B}_{0}=$ Intercept value in the regression of permanent consumption on permanent income is expected to zero 
ISSN: 2362-1303 (Paper) | eISSN: 2362-1311(Online)

$\mathrm{B}_{1}=$ The partial slope coefficient or elasticity of output w. r. t. the expenditure input, where 1 percent change in the capital input, holding the labour input constant.

$B_{2}=$ The partial slope coefficient or elasticity of output w. r. t. the labour input, where 1 percent change in the labour input, holding the capital input constant.

$\mathrm{u}_{\mathrm{i}}=0$, i.e. the stochastic error term which denotes other explanatory variables not specified in the model.

\section{Empirical findings of regression}

The efficiency of agriculture can be defined by the inputs provided such as, expenditure, labour and output agriculture production generated from it. If efficiency is low i.e. large scale inputs can generate small size output. The agriculture sector of Nepal demonstrates less efficiency. To measure the efficiency we can select one of the basic functions the Cobb-Douglas production function. Here we will use:

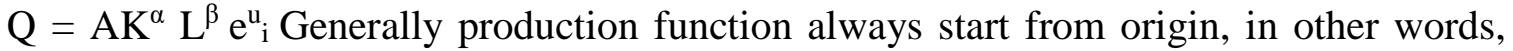
Assuming the line of regression passing through origin and taking Log-Log Model then non-linear model can be converted in to linear equation as,

$\log (\mathrm{Q})=\log \mathrm{A}+\alpha \log (\mathrm{K})+\beta \log (\mathrm{L})+\mathrm{u}_{\mathrm{i}}$

$\log (\mathrm{Q})=\gamma+\alpha \log (\mathrm{K})+\beta \log (\mathrm{L})+\mathrm{u}_{\mathrm{i}}$

Where $\mathrm{Q}$ is output, $\mathrm{K}$ is expenditure / capital, $\mathrm{L}$ is labour and $\mathrm{u}$ is a random error. After taking log we convert the equation to linear so that the coefficients will represent partial elasticity of output with respect to expenditure and labour inputs.

The result from regression can be considered robustness with significant t- values (at 5\%) and residual tests. The regression output and the correlogram of residuals are shown at the Annex 02 table. The regression of equation (1) using Nepalese statistical data for the year $1983 / 84$ to $2013 / 14$ from various resources.

Table 01: Empirical regression results of Agriculture production as dependent variable and Expenditure and Labour are independent variables for large size secondary data.

We already discussed about the movement and relationship between the time series of macroeconomic variables. We now are analyzing the time series annual data of agriculture production and other macroeconomic variables such as, expenditure and labour to see their effects on economic level in agriculture sector of Nepal. However, collective significance test is statistically significance at five percent and individual significance test is significance for expenditure and insignificance for t-statistics in labour. Given non-linear model is change into linear model by log transformation. So we use log form of all variables for the regression purpose 
ISSN: 2362-1303 (Paper) | eISSN: 2362-1311(Online)

JOURNAL OF ADVANCED ACADEMIC RESEARCH (JAAR)

\begin{tabular}{|c|c|c|c|c|c|c|c|c|c|c|c|}
\hline \multicolumn{12}{|c|}{ ANOVA $^{a}$} \\
\hline \multicolumn{3}{|c|}{ Model } & \multicolumn{2}{|c|}{ Sum of Squares } & Df & \multicolumn{3}{|c|}{ Mean Square } & \multicolumn{2}{|l|}{$\mathrm{F}$} & \multirow{2}{*}{\begin{tabular}{|l|} 
Sig. \\
$.000^{\mathrm{b}}$ \\
\end{tabular}} \\
\hline & \multicolumn{2}{|l|}{ Regression } & \multicolumn{2}{|l|}{4.540} & 2 & \multicolumn{3}{|c|}{2.270} & \multicolumn{2}{|c|}{187.042} & \\
\hline 1 & \multicolumn{2}{|l|}{ Residual } & \multicolumn{2}{|l|}{.340} & 28 & & \multicolumn{2}{|c|}{ 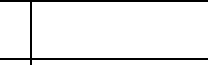 } & \multirow[t]{2}{*}{ 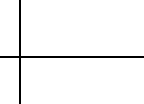 } \\
\hline & \multicolumn{2}{|l|}{ Total } & \multicolumn{2}{|l|}{4.880} & 30 & \multicolumn{3}{|c|}{.012} & & & \\
\hline \multicolumn{12}{|c|}{ Model Summary ${ }^{\mathbf{b}}$} \\
\hline \multicolumn{2}{|c|}{ Model } & $\mathrm{R}$ & R Square & \multicolumn{3}{|c|}{$\begin{array}{ll}\text { Adjusted } & \mathrm{R} \\
\text { Square } & \end{array}$} & \multicolumn{3}{|c|}{$\begin{array}{l}\text { Std. Error of the } \\
\text { Estimate }\end{array}$} & \multicolumn{2}{|c|}{$\begin{array}{l}\text { Durbin- } \\
\text { Watson }\end{array}$} \\
\hline \multicolumn{2}{|c|}{1} & $.965^{\mathrm{a}}$ & .930 & \multicolumn{3}{|c|}{.925} & \multicolumn{3}{|c|}{.11016} & \multicolumn{2}{|l|}{.258} \\
\hline \multicolumn{12}{|c|}{ a. Predictors: (Constant), Lexpenditure, Llabour } \\
\hline \multicolumn{12}{|c|}{ Coefficients $^{\mathrm{a}}$} \\
\hline \multirow{2}{*}{\multicolumn{2}{|c|}{ Model }} & \multicolumn{2}{|c|}{\begin{tabular}{|l|} 
Unstandardized \\
Coefficients
\end{tabular}} & \multicolumn{3}{|c|}{$\begin{array}{l}\text { Standardized } \\
\text { Coefficients }\end{array}$} & \multirow[t]{2}{*}{$\mathrm{T}$} & \multirow[t]{2}{*}{ Sig. } & $\begin{array}{l}95.0^{c} \\
\text { Inter }\end{array}$ & $\begin{array}{l}\% \mathrm{Cor} \\
\text { rval for }\end{array}$ & $\begin{array}{l}\text { nfidence } \\
\text { B }\end{array}$ \\
\hline & & B & Std. Error & Beta & & & & & $\begin{array}{l}\text { Lowt } \\
\text { Boun }\end{array}$ & \begin{tabular}{l|l} 
er & U \\
nd & B
\end{tabular} & $\begin{array}{l}\text { Jpper } \\
\text { Bound }\end{array}$ \\
\hline & (Constant) & 3.816 & .275 & & & & 13.876 & .000 & 3.25 & & .380 \\
\hline 1 & Llabour & .005 & .019 & .014 & & & .271 & .788 & -.034 & & 044 \\
\hline & Lexpenditure & .407 & .021 & .962 & & & 19.008 & .000 & .363 & & 451 \\
\hline
\end{tabular}

\begin{tabular}{|l|l|l|l|l|l|}
\hline \multicolumn{7}{|c|}{ Residuals Statistics $^{\mathbf{a}}$} \\
\hline & Minimum & Maximum & Mean & Std. Deviation & N \\
\hline Predicted Value & 7.0197 & 8.3453 & 7.6949 & .38901 & 31 \\
\hline Residual & -.23594 & .18943 & .00000 & .10643 & 31 \\
\hline Std. Predicted Value & -1.736 & 1.672 & .000 & 1.000 & 31 \\
\hline Std. Residual & -2.142 & 1.720 & .000 & .966 & 31 \\
\hline
\end{tabular}

\section{Summary of SPSS Results}

\begin{tabular}{|l|c|c|c|c|c|c|}
\hline Variables & Coefficients & $\mathrm{R}^{2}$ & t-statistic & $\mathrm{N}$ & F-test & Significance \\
\hline Lproduction & - & 0.930 & - & 31 & 187.042 & 0.000 \\
\hline Lexpenditure & 0.962 & - & 19.008 & 31 & - & 0.000 \\
\hline Llabour & 0.014 & - & 0.271 & 31 & - & 0.788 \\
\hline Constant & - & - & 13.876 & - & - & 0.000 \\
\hline
\end{tabular}

- Dependent Variable : Lproduction

- Predictors : Lexpenditure, Llabour 
ISSN: 2362-1303 (Paper) | eISSN: 2362-1311(Online)

JOURNAL OF ADVANCED ACADEMIC RESEARCH (JAAR)

- Significant at five percent level

- Self calculated by researcher based on Annex II

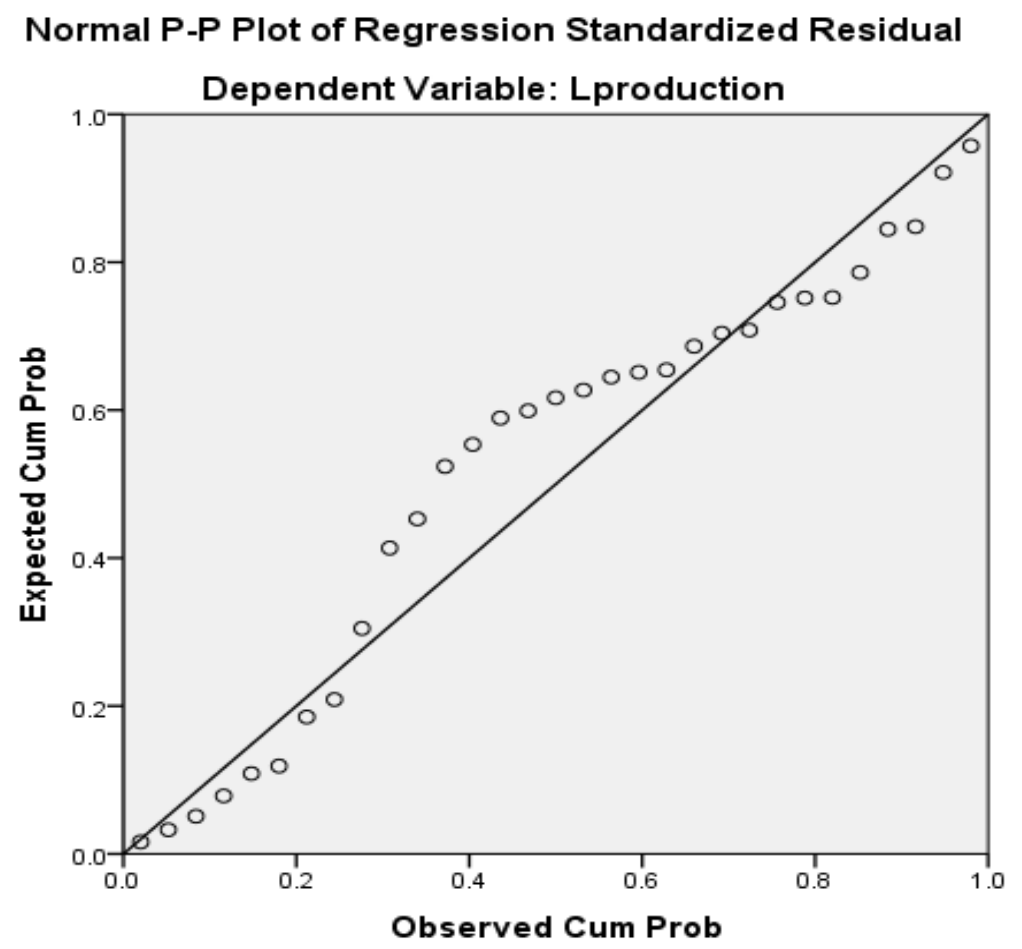

\section{Economic Interpretation of regression results}

Many empirical studies in the past have studied the logical relationship between GDP contribution from agriculture and economic variables such as, expenditure and labour. Most of the studies have concluded positive relationship between production function and economic growth. But in case of Nepal, I found no any significant relationship between these two variables. I have run SPSS software version 20 to get regression coefficients and normal P-P standardized residual dependent variable i.e, production. Model is fitted for aggregative analysis and also at per capita level.

$\log (\mathrm{Q})=\log \mathrm{A}+\alpha \log (\mathrm{K})+\beta \log (\mathrm{L})+\mathrm{u}_{\mathrm{i}}$

$\log (\mathrm{Q})=\gamma+\alpha \log (\mathrm{K})+\beta \log (\mathrm{L})+\mathrm{u}_{\mathrm{i}}$

Where $\mathrm{Q}$ is output, $\mathrm{K}$ is expenditure / capital, $\mathrm{L}$ is labour and $\mathrm{u}$ is a random error. After taking $\log$ we convert the equation to linear so that the coefficients will represent partial elasticity of output with respect to expenditure and labour inputs

$\ln (\mathrm{Q})=\gamma+\alpha \ln ($ expenditure $)+\beta \ln ($ labour $)+\mathrm{u}$

$\ln (\mathrm{Q})=13.876+0.962 \ln ($ expenditure $)+0.014 \ln ($ labour $)$ 
ISSN: 2362-1303 (Paper) | eISSN: 2362-1311(Online)

Considering the 'return to scale' of the coefficients, if $\alpha+\beta=1$ the system is called balanced and if $\alpha+\beta<1$ so the system is less efficient or 'diminishing return to scale'. In our case, $\alpha+\beta=0.962+0.014=0.976<1$ this indicates a diminishing return to scale. Also the partial elasticity, $\alpha=\frac{\delta \log Q}{\delta \log k}=0.962$ and $\beta=\frac{\delta \log Q}{\delta \log L}=0.014$

The study investigated the logical relationship between the agriculture production and expenditure, labour of Nepal by using cross-sectional time series secondary data. CobDouglas production model is used to assess the degree of relationships among variables concerned which show insignificant relationship between production function and economic growth of Nepal. Therefore, agriculture policies of Nepal should be reformulated which to bring conductive in economic growth of the country. Fact findings indicate the following results.

- The output from agriculture is less efficient then economic inputs. For example, for every 100 percent of inputs (agriculture expenditure/investment and labour) .we can expect only 97.60 percent of output(GDP contribution from agriculture). Or more specifically, if Rs 100 is spend for labour generation and Rs 100 for agriculture expenditure/investment, the agriculture GDP will be increased by only Rs 97.60.

- Role of expenditure/investment in agriculture production is very high as compared to the role of labour. In other words, this may be the skilled labour is very low and agriculture production is basically investment/capital incentive.

- The standardized residual in normal P-P plot of regression leads the inverse relationship between observed variables (labour and capital) and expected variable agriculture production in cumulative probability trend line.

- In collective analysis, F- calculated value is 187.042 and tabulated value at five percent level of significance in $\mathrm{F}(2,28)$ is 3.34 in average. It conclude that calculated value is higher than tabulated value, so it concludes statistically significance, This implies that agriculture production on expenditure of government have a positive sign and thus denoting a positive relationship with GDP ( economic growth ) which is expected to exist.

- In individual test( $\mathrm{t}$-statistic) are disperse nature, tabulated value of student $\mathrm{t}$ statistic at five percent level of significance $t(30)$ is 2.024 and calculated value for expenditure is 19.008, sothat it is statistically significance. It means investment/expenditure in agriculture and production are positively correlated to each other while calculated value in labour is 0.271 , it reveals that calculated value is less then tabulated value so, this is positively related in opposite direction.

\section{CONCLUSION}


ISSN: 2362-1303 (Paper) | eISSN: 2362-1311(Online)

Nepal is an agricultural country; about 83 percent of the people's occupation is agriculture. Contribution of agriculture sector to the Nepalese economy has been noteworthy. The agriculture sector occupies almost one third of Gross Domestic Product (GDP) with about two third of country's population are dependent in this sector. Contribution of this sector to GDP was 33.87 percent in fiscal year 2012/13, which is expected to remain at 33.10 percent in fiscal year 2013/14. In fiscal year 2070/71, the annual growth rate of agriculture sector is expected to be 4.72 percent at constant prices of 2000/01.

Empirical research is an ever going and never ending process in production function of Nepal. To identifying the impact of agriculture production on economic growth, data were collected from secondary sources from economic survey in 1983/84 to 2013/14 in averages. Empirical result reveals that the determination of regression is 0.93 . It shows that ninety three percent of explained variable i.e. agriculture production on the basis of inputs or economic variables i.e. expenditure and labour, rest 0.07 percent occur due to the error. Furthermore, in collective analysis F-calculated value 187.042 is higher than tabulated value 3.34 at five percent level of significance. It is statistically significance whereas; individual student t-statistic is disperse nature. It is clear to see that fact finding of CobDouglas production function, where 1 percent change expenditure and labour inputs leads to 0.976 percent change in production function. So system is less efficient or diminishing return to scale.

As a result, economic performance of the Nepalese economy is not improving despite change in agriculture policy issues. So, agriculture production policies should be interlinked with macroeconomic policies.

\section{REFERENCES}

Anderson, T.W., and C. Hsiao. 1982. "Formulation and Estimation of Dynamic Models Using panel Data.”Journal of Econometrics 18: 47-82.

CBS (Central Bureau of Statistics). 2011. "Nepal Living Standard Survey.” Kathmandu:

CBS. Retrieved from www.cbs.gov.np

Chiang,A.C, and Wainwright, K. 2013."Fundamental method of Mathematical Economics.” (4thed.). New Delhi : McGraw Hill Education publication Pvt.Ltd.

Gujarati, D.N., Porter, D.C., \&Gunasekar, S. 2012. "Basic Econometrics." New Delhi: McGraw Hill Edication, India.

Karki, B. 2070.'Nepal's Agriculture : Opportunities and constraints.” Kathmandu, NRB, ArthikSagalo, pp 178-186.

Mainali, P.K.2071. "Government Expenditure on agriculture and non-agriculture headings and their impact on respective sector." Kathmandu, NRB, Samachar, Vol 59 pp 7080.

Mankiw, N.G. 2012."Principles of Microeconomics.” (6thed.). New Delhi :Cengage Learning India Pvt.Ltd.

Ministry of Finance. 2015. "Economic Survey”. Kathmandu: MOF, Government of Nepal. Ministry of Finance. 2014. "Economic Survey." Kathmandu: MOF, Government of Nepal 
ISSN: 2362-1303 (Paper) | eISSN: 2362-1311(Online)

MOAD, 2013."Statistical information on Nepalese Agriculture, Agri-business promotion and Statistics Division," Ministry of Agricultural Development, Kathmandu, Nepal.

National Planning Commission Secretariat .2011.“Nepal Vegetable Crops Survey.”CBS Kathmndu: Government of Nepal.

National Planning Commission Secretariat. 2013. "National Sample Census of Agriculture Nepal.” CBS Kathmndu: Government of Nepal.

Satyal, V.R. 2011.“Agriculture in Decline.” Department of Economic, TU: Economic Journal of Development of Issues. Vol. 11 pp.1-18.

Shapiro, E. 2001."Macroeconomc analysis." (Fifth ed.). New Delhi: Galgotia Publications Pvt.Ltd.

Wagle, T.P. 2014.“Agriculture Production in Nepal : A Theoretical and an Empirical Analysis,"Saraswoti Multiple campus, TU : Journal of Development Review, Vol 3 pp 160-165.

Zhengfei, G. 2005. "Econometric Analysis of Agricultural Production." Unpublished Ph. D .Dessartation, Ponsen\&LooijenBV :Wageningen University, Netharland

\section{Annex-I}

Large size secondary panel data:

$\begin{array}{lllll}\text { Year } & \text { Area } & \begin{array}{l}\text { Production } \\ \text { O00' Metric-ton }\end{array} & \text { Labour/Male } & \begin{array}{l}\text { Expenditure/ } \\ \text { at current price } \\ \text { as in ten-million }\end{array} \\ & & & & \\ 1983 / 84 & \text { Illam } & 1165.1 & 144125 & 2257 \\ 1984 / 85 & \text { Jhapa } & 1231 & 385284 & 2276.1 \\ 1985 / 86 & \text { Rasuwa } & 1284 & 21775 & 2713.6 \\ 1986 / 87 & \text { Kathmandu } & 1431.71 & 909786 & 3062.3 \\ 1987 / 88 & \text { Manang } & 1411.92 & 3664 & 3675.5 \\ 1988 / 89 & \text { Gorkha } & 1483.1 & 120541 & 4257.2 \\ 1989 / 90 & \text { Syangja } & 1620.1 & 125872 & 5047 \\ 1990 / 91 & \text { Palpa } & 1633.88 & 119167 & 5536.8 \\ 1991 / 92 & \text { Dang } & 1784.54 & 264110 & 6515.6 \\ 1992 / 93 & \text { Doti } & 1907.64 & 97007 & 7009 \\ 1993 / 94 & \text { Kapilvastu } & 1936.69 & 284813 & 8058.9 \\ 1994 / 95 & \text { Magu } & 2023.63 & 28197 & 8556.9 \\ 1995 / 96 & \text { Pyuthan } & 1909.6 & 103459 & 9689.6 \\ 1996 / 97 & \text { Siraha } & 1778.23 & 313292 & 10878.5 \\ 1997 / 98 & \text { Baitadi } & 1837.8 & 118015 & 11249.5 \\ 1998 / 99 & \text { Humla } & 1798.57 & 25940 & 13237.3 \\ 1999 / 00 & \text { Jumla } & 1936.99 & 54790 & 14513.1 \\ 2000 / 01 & \text { Mahottari } & 2140.31 & 320886 & 15378.1 \\ 2001 / 02 & \text { Sarlahi } & 2211.71 & 388872 & 16392.5 \\ 2002 / 03 & \text { Bara } & 2318.83 & 358144 & 17063.4\end{array}$


ISSN: 2362-1303 (Paper) | eISSN: 2362-1311(Online)

JOURNAL OF ADVANCED ACADEMIC RESEARCH (JAAR)

July 2016

$\begin{array}{lllll}2003 / 04 & \text { Dhading } & 2401.5 & 157928 & 18362.1 \\ 2004 / 05 & \text { Khotang } & 2629.79 & 98860 & 19668.6 \\ 2005 / 06 & \text { Salyan } & 2725.55 & 116615 & 20859.1 \\ 2006 / 07 & \text { Saptari } & 2873.77 & 316888 & 22353.6 \\ 2007 / 08 & \text { Baglung } & 3169.46 & 119021 & 24332.3 \\ 2008 / 09 & \text { Chitawan } & 3440.61 & 272289 & 30547.7 \\ 2009 / 10 & \text { Lalitpur } & 3711 & 237114 & 39151.9 \\ 2010 / 11 & \text { Makawanpur } & 4034.6 & 210564 & 47327 \\ 2011 / 12 & \text { Udayapur } & 4613.57 & 151649 & 50046.5 \\ 2012 / 13 R & \text { Taplejung } & 8453.25 & 61442 & 52786.9 \\ 2013 / 14 P & \text { Kanchanpur } & 4707.5 & 213109 & 58369.2\end{array}$

Sources : Population Census 2011,CBS. MOF, and MOAD. 